DEMOGRAPHIC RESEARCH

VOLUME 31, ARTICLE 12, PAGES 319-336

PUBLISHED 31 JULY 2014

http://www.demographic-research.org/Volumes/Vol31/12/

DOI: 10.4054/DemRes.2014.31.12

Descriptive Finding

\title{
Fertility and education in Poland during state socialism
}

\section{Zuzanna Brzozowska}

(C) 2014 Zuzanna Brzozowska.

This open-access work is published under the terms of the Creative Commons Attribution NonCommercial License 2.0 Germany, which permits use, reproduction \& distribution in any medium for non-commercial purposes, provided the original author(s) and source are given credit.

See http://creativecommons.org/licenses/by-nc/2.0/de/ 


\section{Table of Contents}

$\begin{array}{lll}1 & \text { Introduction } & 320\end{array}$

$2 \quad$ Data and methods 320

2.1 Data 320

2.2 Methods 322

$3 \quad$ Results 324

3.1 Educational differences in completed fertility 324

3.2 Decomposition of the fertility changes 325

$4 \quad$ Discussion and conclusions 327

5 Acknowledgments 329

References 330

Appendix 330 


\title{
Fertility and education in Poland during state socialism
}

\author{
Zuzanna Brzozowska ${ }^{1}$
}

\begin{abstract}
BACKGROUND

Studies on fertility in Poland focus on the turbulent transition period and its consequences. However, during state socialism significant societal and demographic changes took place.
\end{abstract}

\section{OBJECTIVE}

This article studies the macro-level relationship between education and completed fertility of Polish women born between 1930 and 1959, and tries to assess how changes in women's educational structure affected fertility.

\section{METHODS}

Using data from the large-scale Fertility Survey 2002 that accompanied the Polish population census, I first look into fertility trends by education and five-year cohorts. Then, by applying Cho's and Retherford's decomposition analysis and direct standardisation, I assess the role of women's educational expansion in fertility changes.

\section{RESULTS}

Despite profound structural changes and the ruling egalitarian ideology, the educational gradient in completed fertility remained strongly negative in all analysed cohorts. The observed decline in completed fertility from 2.51 in the 1930-34 cohort to 2.22 in the 1955-59 cohort can be explained by the expansion of female education. Had the educational structure not changed, the completed fertility of the youngest cohort would have been slightly higher than that of the oldest cohort.

\section{CONCLUSIONS}

Under state socialism in Poland, better-educated women had on average fewer children than the less educated. The expansion of female education played an important role in fertility decline.

\footnotetext{
${ }^{1}$ Vienna Institute of Demography, Austrian Academy of Sciences, Austria.

E-Mail: Zuzanna.Brzozowska@oeaw.ac.at.
} 


\section{Introduction}

Studies on fertility in Poland mostly focus on the transition and post-transition period (Kotowska et al. 2008; Okólski 2006, 2007), contrasting the dynamic reality of the market economy with the predictability and stability of state socialism. It was, however, the People's Republic of Poland that experienced an educational revolution and shifted millions of people up to the basic vocational and secondary educational levels. It was also under state socialism that the average number of children a woman gave birth to (i.e., the completed fertility rate, CFR) declined substantially, from 2.8 to 2.2 in the 1930 and 1960 cohorts, respectively (Council of Europe 2005).

The likely strength of the relationship between education and fertility in communist Poland is difficult to assess, as there have been few studies on this topic. As, officially, the political system strove for equality in every aspect of life, one would expect small differences in fertility by the level of education. In practice, however, daily life was marked by social inequalities, which together with a means-tested family policy would speak for considerable educational differences in fertility, on a par with those in the Czech Republic, Russia, or Slovakia (Potančoková et al. 2008; Sobotka et al. 2008; Zakharov 2008).

This paper examines the relationship between education and cohort-completed fertility under state socialism in Poland. It describes fertility trends by education and quantifies the effect of female educational expansion on cohort fertility. In the last section it also discusses the meaning of education in Polish society during state socialism.

\section{Data and methods}

\subsection{Data}

The data come from the Fertility Survey that accompanied the 2002 Polish population census. From a representative sample of 264,845 women born between 1896 and 1986 I chose 116,969 females born between 1930 and 1959 (i.e., aged 43 to 72 at the time of the interview). After deleting cases with missing information on the number of children and on education, the final sample analysed in this paper covers 116,116 women (see Table A1 in Appendix for the distribution by cohort and education). The observations were weighted with post-stratification weights calculated from the Population Census 2002 by the Central Statistical Office.

All the analyses were carried out using four educational categories, which correspond to the following levels of the International Standard Classification of 
Education (ISCED) ${ }^{2}$ : primary and lower (up to 7-8 years of schooling, ISCED 0, 1, and 2); basic vocational (9-11 years of schooling, ISCED 3C); secondary (11-14 years of schooling, ISCED $3 \mathrm{AB}$ and 4 ); and tertiary (16 and more years of schooling, ISCED 5 and 6). Basic vocational education leads to skilled-worker jobs such as hairdresser, cook, or car mechanic. The category "secondary education" includes comprehensive and vocational secondary school, lasting for 4 and 5 years, respectively, and 1 to 2 years of post-secondary non-tertiary education. ${ }^{3}$ Comprehensive secondary school was usually chosen by people who were either planning to attend university afterwards or to acquire non-tertiary education, e.g., qualifications for jobs like nurse, secretary, or technician. Vocational secondary school graduates either decided on tertiary education or directly entered the labour market, working as technicians or highly skilled workers. Due to its very small numbers, the post-tertiary education (ISCED 6) category was merged with the tertiary level (ISCED 5). A university diploma provided eligibility for professions such as teacher, physician, lawyer, or other specialist; technical occupations like engineer were relatively seldom chosen by women.

The distribution by cohort and education of the cleaned and weighted sample is presented in the graph below (Figure 1).

In the sample there are considerably fewer women born before and during the Second World War than afterwards (see Table A1 in Appendix), which raises doubts about the representativeness of the cohorts born before 1946. Including respondents at high ages in the analysis adds a potential source of bias, but there are good reasons for doing so, nonetheless. First, as seen in Figure 1, the cumulative distribution of educational attainment does not show any irregularities for cohorts born before 1946 . There are some ups and downs among women with primary and basic vocational education born between 1932 and 1945, but the trend is very consistent: with time, the proportion of the least educated declines drastically, the proportion of women with basic vocational and secondary education increases sharply, and the proportion of those with tertiary education gradually goes up. Second, retrospective analyses conducted on women aged up to 70 and more are not uncommon in contemporary demography (cf. Neels and De Wachter 2010). Third, the completed fertility of female cohorts born 1930 and after published by the Council of Europe (2005) differs little from the completed

2 I use the 1997 ISCED version. For details, please visit http://www.uis.unesco.org/Education/Pages/ international-standard-classification-of-education.aspx.

${ }^{3}$ Secondary education could be disaggregated into comprehensive and vocational secondary education (see Figure A1 in Appendix for the cumulative distribution). However, in terms of fertility these two groups hardly differed. That is why they are kept as one category. Secondary and post-secondary non-tertiary education have been merged into one for two reasons. First, the number of women with the latter education level was too small to analyse separately. Second, the fertility behaviour of women with that education level very much resembled that of women with secondary education. 
fertility calculated here: the difference amounts to 5\% and 6\% for the 1935 and 1940 cohorts, respectively (for details see Table A2 in Appendix).

\section{Figure 1: Cumulative distribution by cohort and education at the time of the interview (in per cent)}

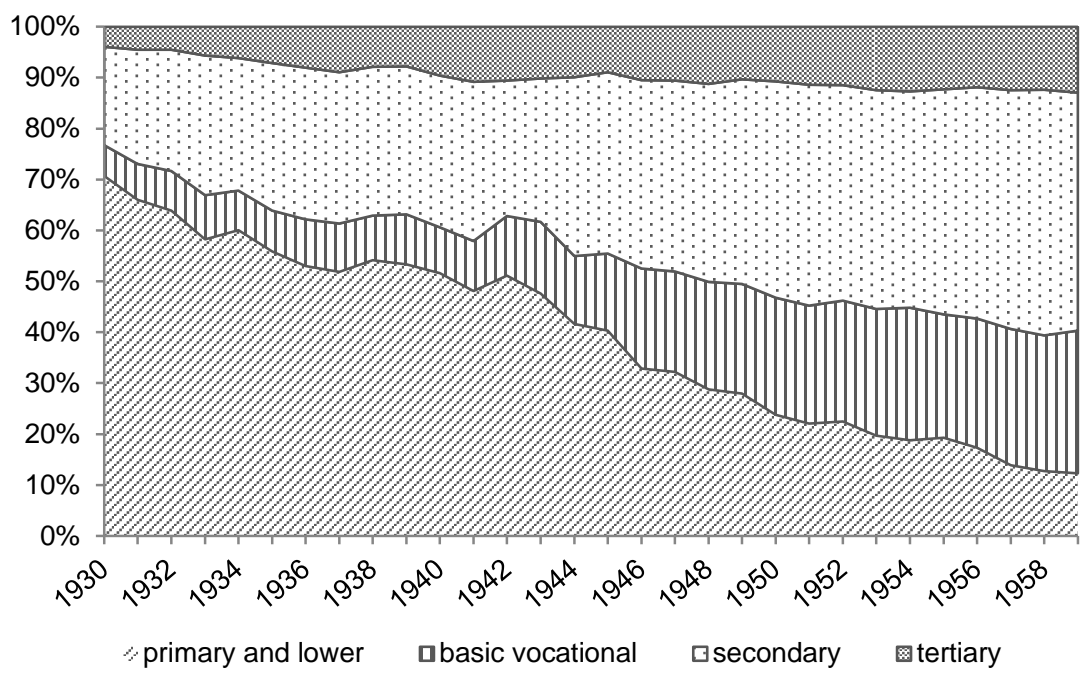

Source: Author's own calculations based on Fertility Survey 2002

For the sake of comparability over cohorts, I assumed that women's reproductive careers end at age 43 (as the youngest analysed cohort was 43 years old at the time of the interview). This common practice of ignoring a very minor portion of fertility at very high childbearing ages (Cohen et al. 2011; Kravdal and Rindfuss 2008) allowed me to include as many as 30 cohorts in the analysis with a loss of not more than $0.5 \%$ of the cohort completed fertility (see Table A2 in the Appendix for a comparison of the truncated and completed fertility with the completed fertility given by the Council of Europe).

\subsection{Methods}

First, I analyse the completed fertility trends by education. Then I conduct a twocomponent decomposition, drawing on Cho's and Retherford's work (Canudas Romo 2003; Cho and Retherford 1973), which is a simple extension of the Kitagawa 
decomposition called "components of a difference between two rates" (Kitagawa 1955). Applying her decomposition framework, the difference between the CFR of cohorts born in year $t$ and year $t+h$ can be split into a change (1a) in the educational structure (compositional component) and (1b) in the specific (standardised) completed fertility rates (direct component):

$$
\begin{array}{r}
\Delta C F R(t)=\sum_{i}\left[\frac{C F R(t+h)_{i}+C F R(t)_{i}}{2} *\left(\omega(t+h)_{i}-\omega(t)_{i}\right)\right] \\
+\sum_{i}\left[\frac{\omega(t+h)_{i}+\omega(t)_{i}}{2} *\left(C F R(t+h)_{i}-C F R(t)_{i}\right)\right]
\end{array}
$$

where: $\omega(t)_{i}=\frac{n(t)_{i}}{n(t)}$ and $\omega(t+h)_{i}=\frac{n(t+h)_{i}}{n(t+h)}$, and denote the proportion of educational group $i$ in the cohorts $t$ and $t+h$, respectively.

In order to relate the fertility changes to period, I further decompose expression (1b) into the standardised age-specific fertility rates (ASFRs). For simplicity and clarity, let us call it the difference in the standardised fertility component (and denote it as $\triangle \mathrm{SFC}$ ). As the CFR is calculated as the sum of ASFRs, i.e.,

$$
C F R=\sum_{j} A S F R_{j},
$$

the decomposition can be written as:

$$
\begin{gathered}
\Delta S F C(t)=\sum_{i}\left[\frac{\omega(t+h)_{i}+\omega(t)_{i}}{2} * \sum_{j} \operatorname{ASFR}(t+h)_{i j}-\operatorname{ASFR}(t)_{i j}\right]= \\
\sum_{j} \sum_{i}\left[\frac{\omega(t+h)_{i}+\omega(t)_{i}}{2} *\left(\operatorname{ASFR}(t+h)_{i j}-\operatorname{ASFR}(t)_{i j}\right)\right]
\end{gathered}
$$

Each $j$ component of $\triangle \mathrm{SFC}$ represents the change in fertility in one of five age groups (under 20, 20-24, 25-29, 30-34, and over 34, which means here 35-43 and is further denoted as "35 and more"). The final decomposition equation can be written as follows:

$$
\begin{aligned}
& \quad C F R(t+h)-\operatorname{CFR}(t)=\sum_{i}\left[\frac{\operatorname{CFR}(t+h)_{i}+C F R(t)_{i}}{2} *\left(\omega(t+h)_{i}-\omega(t)_{i}\right)\right] \\
& +\sum_{j} \sum_{i} \frac{\omega(t+h)_{i}+\omega(t)_{i}}{2} *\left(\operatorname{ASFR}(t+h)_{i j}-\operatorname{ASFR}(t)_{i j}\right)
\end{aligned}
$$

In order to assess the role of education and standardised fertility in the CFR decrease between the oldest and the youngest analysed cohorts, I apply formulas (1ab) and (3) to women born in years 1930-34 and 1955-59. Then, for the purpose of examining trends, I repeat the decomposition analyses for all neighbouring five-year 
cohorts. Additionally, I employ direct standardisation to show how the CFR would have changed if the educational structure had remained stable.

\section{Results}

\subsection{Educational differences in completed fertility}

Despite the extensive changes in female educational structure, the educational differences in completed fertility remained sharp throughout the analysed cohorts: on the whole, the better educated a woman was the fewer children she had (Figure 2).

The completed fertility of women born between 1930-34 and 1940-44 declined linearly from 2.51 to 2.22, and then it levelled off. Within the educational groups, however, it was on the increase for most of the cohorts. Comparing the oldest and the youngest cohorts, fertility went up among women with basic vocational education (from 2.29 to 2.45), and with secondary (from 1.91 to 2.04) and tertiary (from 1.53 to 1.67) education, whereas the fertility of the least educated remained almost at the same level (2.84 and 2.82, respectively). Their fertility seems to have been most distinctive: on average, they had 0.45 and 1.2 children more than women with basic vocational and tertiary education, respectively.

\section{Figure 2: Completed fertility rate (CFR) at age 43, by cohort and education}

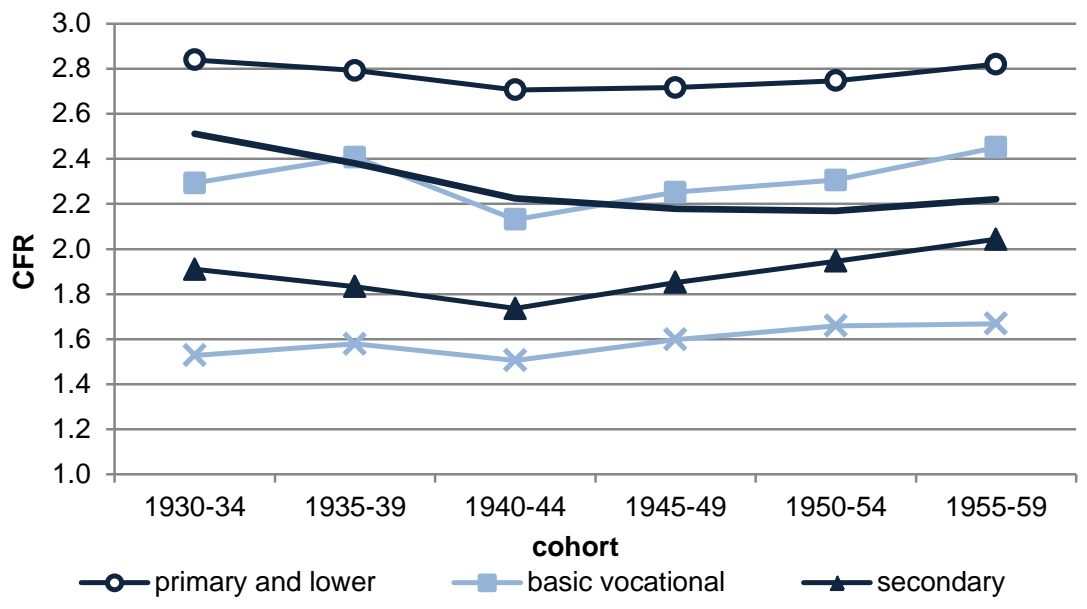

Source: Author's own calculations based on the Fertility Survey,2002 


\subsection{Decomposition of the fertility changes}

The decomposition results for the oldest and the youngest five-year cohorts suggest that the fertility decline of 0.29 children per woman can be explained by changes in educational structure and that fertility net of educational changes actually increased by almost 0.1 (see the upper panel of Table 1). It looks as if the compositional effect played a much more important role than the direct one. However, the decomposition of fertility changes in the subsequent five-year cohorts (Table 1) shows that this impression is misleading. The educational structure was changing in one direction (the least educated group was shrinking while all the others were growing), while fertility net of educational changes went down in the two older cohorts (1935-39 and 1940-44) and then increased in the three younger cohorts. Consequently, the CFR declined sharply between the 1930-34 and 1935-39 cohorts (-0.13) and between the 1935-39 and 1940-44 cohorts (-0.16). In the case of cohorts born after 1944, the negative structural effect was counterbalanced by the positive direct effect. This made the CFR decline more modest: in the last cohort the CFR actually increased by 0.05 compared to the previous cohort (1950-54).

Table 1: CFR and its change over five-year cohorts

\begin{tabular}{|c|c|c|c|c|}
\hline \multirow[t]{2}{*}{ cohort } & \multirow[t]{2}{*}{ CFR } & \multirow[t]{2}{*}{ change in CFR } & \multicolumn{2}{|c|}{ Decomposition of the change in CFR: } \\
\hline & & & direct effect & compositional effect \\
\hline $\begin{array}{l}1955-59 \text { to } \\
1930-34\end{array}$ & & -0.29 & 0.08 & -0.37 \\
\hline 1930-34 & 2.51 & - & - & - \\
\hline 1935-39 & 2.38 & -0.13 & -0.04 & -0.10 \\
\hline 1940-44 & 2.22 & -0.16 & -0.11 & -0.05 \\
\hline $1945-49$ & 2.18 & -0.05 & 0.07 & -0.12 \\
\hline 1950-54 & 2.17 & -0.01 & 0.06 & -0.07 \\
\hline 1955-59 & 2.22 & 0.05 & 0.09 & -0.04 \\
\hline
\end{tabular}

Source: Author's own calculations based on Fertility Survey 2002.

Note: Computations based on equation (1ab).

The very strong compositional effects in the 1935-39 and 1945-49 cohorts are due to a sharp drop in the proportion of least educated but most fertile women: -10 and -16 percentage points between the 1930-34 and 1935-39 and between the 1940-44 and 1945-49 cohorts, respectively (results not shown; compare Figure 1 for educational 
structure of one-year cohorts). In the 1935-39 cohort the most substantial increases were found in the share of women with secondary and tertiary education, and in the 1945-49 cohort it was the group with secondary and basic vocational education that grew most.

The graph below (Figure 3) clearly shows the role that changes in female educational structure played in the fertility decline. It compares the observed CFR with a directly standardised one, i.e., the CFR that would have been observed if the educational structure had not changed.

Figure 3: The real and standardised CFR at age 43

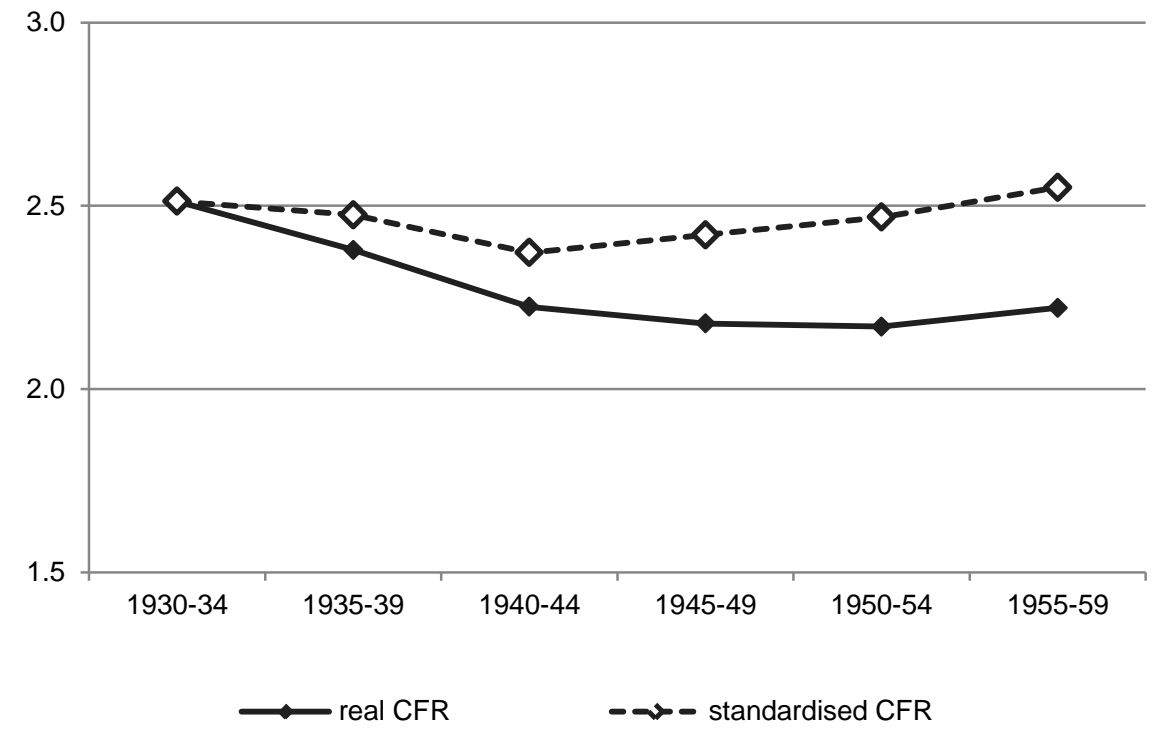

Source: Author's own calculations based on Fertility Survey 2002.

Note: Computations based on direct standardisation of the CFR (the educational structure of the 1930-34 cohort is the standard one).

Not surprisingly, the gap between the real and the standardised CFR is getting wider with time. In the last five-year cohort it reaches 0.33 children per woman (2.22 vs. 2.55). Thus, had the educational structure remained constant, the completed fertility of the youngest five-year cohort would have not declined. On the contrary, it would have been 0.04 higher than that of the oldest one. 
Further decomposition of the direct effect (i.e., computing the standardised fertility component: see equation (3)) suggests that the cohort changes in fertility (net of educational changes) at the most fertile ages were time-clustered (Figure 4).

Figure 4: The calendar time of decreases and increases in the standardised ASFRs over five-year cohorts

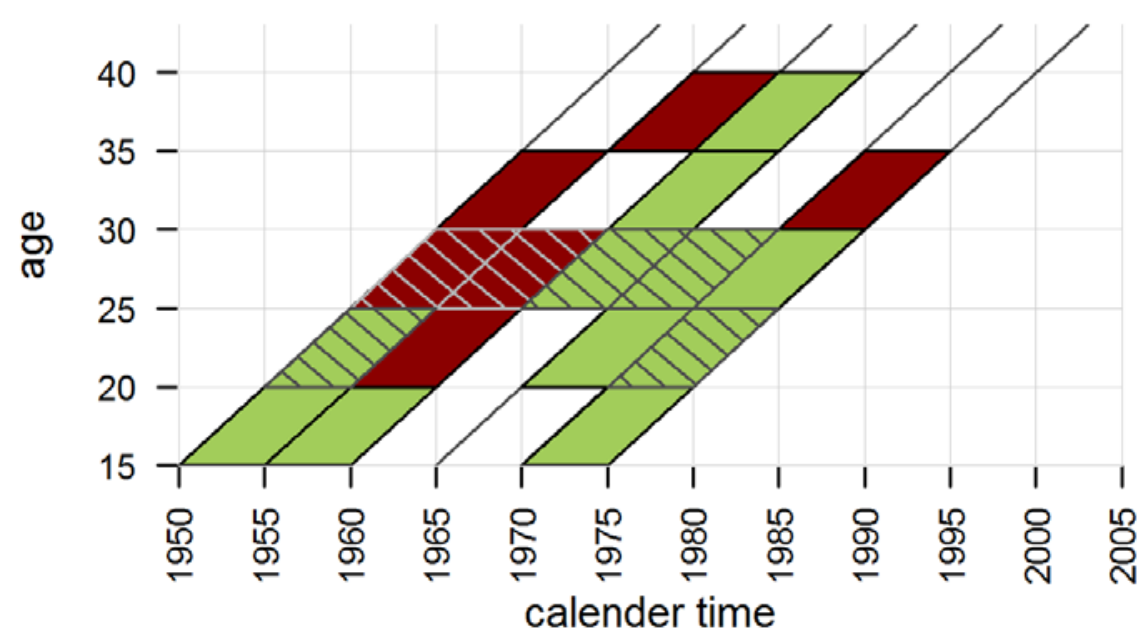

Note: Dark (red) and light (green) colours represent the decreases and increases, respectively. Only changes of

$(-) 0.02$ and above are coloured; the biggest changes, between (-)0.05 and (-)0.07, are shaded.

Most of the decreases took place in the 1960s, whereas the increases occurred in two waves: in the 1950s and between the 1970s and the mid-1980s. The former increases referred to fertility of teenagers and women between 20 and 24 years old; the latter ones included fertility of teenagers (cohort 1955-59), women in their 20s (cohorts 1945-49, 1950-54 and 1955-59) and 30s (cohort 1945-49).

\section{Discussion and conclusions}

This study shows that the decline in completed fertility of Polish women born between 1930-34 and 1955-59 can be explained by profound changes in female education structure: had it remained stable, fertility would have actually increased. The educational differences in completed fertility in all analysed cohorts were large and persistent: the average difference in CFR of women with at most primary education and 
those with tertiary education amounted to 1.16 (1.3 and 1.15 in the oldest and youngest cohorts, respectively).

In view of the egalitarian ideology of state socialism, the stable negative educational gradient in completed fertility might seem surprising. It cannot be interpreted from the opportunity costs perspective, as job alternatives for women were limited, regardless of their education (Fidelis 2010 chap.6; Titkow 1993; Zembrzuska 2000). Ideational changes associated with the second demographic transition cannot serve as an explanation either, since these could not have appeared within or co-existed with a socialist system. Below, I give possible explanations discussed in the literature. Their testing needs further research.

Despite the leading role of the working class, officially declared by the state and guaranteed by the 1952 Constitution (National Constituent Assembly 1952), the concept of traditional social hierarchy remained deeply embedded in Polish society throughout the communist period. In a non-meritocratic country, in which blue-collar workers often earned more than white-collar workers (Rutkowski 1996), education rather than the financial status was of central importance as a determining factor of social status. Thus highly educated people, the so-called 'intelligentsia', drew a clear distinction between their social class and the others by leading a 'bourgeois' lifestyle. They engaged in reading, went on holiday abroad if possible, sent their children to private piano lessons, or enabled them to take private English or French classes (Domański 2004; Giza-Poleszczuk 2007; Szacka 2008 chap.14). Contrary to the official ideology and policy, they embodied Becker's theory of raising children of high quality (Becker 1991). Considering their low earnings this led to a quantity-quality trade-off.

The secondary-educated ranked one level behind in the social hierarchy, aiming to lead a similar lifestyle to the 'intelligentsia'. In general, people of a less educated background who wanted to push their children up the social ladder, tried to adopt the ideals and manners of the better educated strata (Domański 2004). In times of great upward social mobility, this behaviour inevitably led to a decline in cohort fertility. On the other hand, the adaptation was usually incomplete. The expansion of basic vocational and secondary and, to a lesser extent, tertiary education might have been the reason why fertility increased in these educational groups. With time they became more and more heterogeneous, absorbing people from less educated social backgrounds and of originally different values and lifestyles (Domański 2007 chap.14.3, 2004). This might explain the slightly narrowing gap in completed fertility between women with at most primary and basic vocational education (differences of 0.55 and 0.37 in the oldest and youngest cohorts, respectively), and between women with secondary and tertiary education (differences of 0.38 and 0.29 in the 1930-34 and the 1950-54 cohorts, respectively). An opposite process took place in the least-educated group. It became more selective, which might explain the stability of its completed fertility. 
The increase in completed fertility net of educational changes, observed between the oldest and the youngest cohort, was entirely due to the increasing fertility of women under 25 years old (see the last column in Table A3 in Appendix). This might be the result of a mortality selection effect, which to some extent certainly affected the oldest cohort. However, it might also be an indicator of changing fertility patterns: HolzerŻelażewska and Tymicki (2009) have shown that fertility among women under 25 was much lower in the first post-war cohort (1946) than in the 1960 cohort. This finding shows that the fertility postponement in the post-educational phase that took place in capitalist Europe (Ní Bhrolcháin and Beaujouan 2012) was not observed in communist Poland (nor most probably in other European countries behind the Iron Curtain). This is in line with the explanation of early parenthood in the socialist countries given by van de Kaa (1994), that setting up a family there was a way of gaining independence. Centrally planned economies suffered from a persistent housing shortage, and being single or living as a childless couple reduced the chances of moving out of the parental home to almost zero.

Finally, the timing of the ASFR increases might be associated with the substantial changes in parental leave policy that were introduced in 1968, 1972, and 1981 (Frątczak et al. 2007; Kurzynowski 2000; Zembrzuska 2000; compare Spéder and Kamarás 2008 for Hungary).

In sum, the educational differences in completed fertility under state socialism in Poland were substantial and persistent: better educated women had on average fewer children than the less educated. The expansion of female education played an important role in fertility decline.

\section{Acknowledgments}

This study was conducted within the EURREP project which is funded by the European Research Council under the European Union"s Seventh Framework Programme (FP7/2007-2013)/ERC Grant agreement $\mathrm{n}^{\circ}$ 284238. I am very grateful to Tomáš Sobotka, Janina Jóźwiak, Éva Beaujouan, Andrew Hinde, and two anonymous reviewers for their valuable comments on an earlier draft of this paper. I would also like to thank Inga Freund and Werner Richter for language editing. 


\section{References}

Becker, G.S. (1991). A Treatise on the Family. Revised and Enlarged Edition. Cambridge, Massachussetts: Harvard University Press.

Canudas Romo, V. (2003). Decomposition Methods in Demography. Groningen: Rijksuniversiteit Groningen.

Cho, L.J. and Retherford, R.D. (1973). Comparative analysis of recent fertility trends in East Asia. In: International Union for the Scientific Study of Population (eds.). Proceedings of the 17th General Conference of the IUSSP. Liège, Belgium: IUSSP: 163-181.

Cohen, J.E., Kravdal, Ø., and Keilman, N. (2011). Childbearing impeded education more than education impeded childbearing among Norwegian women. Proceedings of the National Academy of Sciences of the United States of America 108(29): 11830-11835. doi:10.1073/pnas.1107993108.

Council of Europe (2005). Recent demographic developments in Europe. Strasbourg: Council of Europe.

Domański, H. (2004). O ruchliwości społecznej w Polsce. Warsaw: IFiS PAN.

Domański, H. (2007). Struktura społeczna. Warszawa: Wydaw. Naukowe Scholar.

Fidelis, M. (2010). Women, Communism, and Industrialization in Postwar Poland. New York: Cambridge University Press.

Frątczak, E., Kulik, M., Malinowski, M.; and Słotwińska-Rosłanowska, E. (2007). Regulacje prawne $w$ odniesieniu do zjawisk i procesów demograficznych. Wybrane akty prawne regulujące świadczenia na rzecz dzieci i rodziny - polityka spoteczna polska, wybrane lata 1945-2006. Warszawa: Komitet Nauk Demograficznych PAN.

Giza-Poleszczuk, A. (2007). Rodzina i system społeczny. In: Marody, M. (ed.). Wymiary życia społecznego. Warsaw: Wydawnictwo Naukowe scholar.

Holzer-Żelażewska, D. and Tymicki, K. (2009). Cohort and period fertility of Polish women, 1945-2008. Studia Demograficzne 155(1): 48-69.

Kitagawa, E.M. (1955). Components of a Difference Between Two Rates. Journal of the American Statistical Association 50(272): 1168-1194. 
Kotowska, I., Jóźwiak, J., Matysiak, A., and Baranowska, A. (2008). Poland: Fertility decline as a response to profound societal and labour market changes? Demographic Research 19(22): 795-854. doi:10.4054/DemRes.2008.19.22.

Kravdal, Ø. and Rindfuss, R.R. (2008). Changing Relationships between Education and Fertility: A Study of Women and Men Born 1940 to 1964. American Sociological Review 73(5): 854-873. doi:10.1177/000312240807300508.

Kurzynowski, A. (2000). Przemiany wzorów karier zawodowych kobiet w latach 19501989. In: Żarnowska, A. and Szwarc, A. (eds.). Kobieta i praca. Warszawa: DiG: $189-216$.

National Constituent Assembly (1952). Konstytucja Polskiej Rzeczypospolitej Ludowej uchwalona w dniu 22 lipca 1952 r. http://www.trybunal.gov.pl/wszechnica/ akty/konstytucja_prl.htm.

Neels, K. and De Wachter, D. (2010). Postponement and recuperation of Belgian fertility: how are they related to rising female educational attainment? Vienna Yearbook of Population Research 8: 77-106. doi:10.1553/populationyearbook 2010 s77.

Ní Bhrolcháin, M. and Beaujouan, É. (2012). Fertility postponement is largely due to rising educational enrolment. Population Studies 66(3): 311-327. doi:10.1080/ 00324728.2012.697569.

Okólski, M. (2006). Płodność i rodzina w okresie tranformacji. In: Wasilewski, J. (ed.). Wspótczesne społeczeństwo polskie - dynamika zmian. Warszawa: Wydawn. Nauk Scholar

Okólski, M. (2007). Przemiany ludnościowe we współczesnej Polsce z perspektywy minionego stulecia. In: Marody, M. (ed.). Wymiary życia spolecznego. Polska na przetomie XX i XXI w. Warszawa: Wydawn. Nauk Scholar: 27-66.

Potančoková, M., Vano, B., Pilinská, V., and Jurcová, D. (2008). Slovakia: Fertility between tradition and modernity. Demographic Research 19(25): 973-1018. doi:10.4054/DemRes.2008.19.25.

Prskawetz, A., Sobotka, T., Buber, I., Engelhardt, H., and Gisser, R. (2008). Austria: Persistent low fertility since the mid-1980s. Demographic Research 19(12): 293-360. doi:10.4054/DemRes.2008.19.12.

Rutkowski, J. (1996). High skills pay off: the changing wage structure during economic transition in Poland. Economics of Transition 4(1): 89-112. doi:10.1111/j.14680351.1996.tb00163.x. 
Sobotka, T., Št’astná, A., Zeman, K., Hamplová, D. and Kantorová, V. (2008). Czech Republic: A rapid transformation of fertility and family behaviour after the collapse of state socialism. Demographic Research 19(14): 403-454. doi:10.4054/DemRes.2008.19.14.

Spéder, Z. and Kamarás, F. (2008). Hungary: Secular fertility decline with distinct period fluctuations. Demographic Research 19(18): 599-664. doi:10.4054/ DemRes.2008.19.18.

Szacka, B. (2008). Wprowadzenie do socjologii. Warsaw: Oficyna Naukowa.

Titkow, A. (1993). Political Change in Poland: Cause, Modifier, or Barrier to Gender Equality? In: Funk, N. and Mueller, M. (eds.). Gender politics and postcommunism: reflections from eastern Europe and the former Soviet Union. London: Routledge.

Van de Kaa, D.J. (1994). The second demographic transition revisited: Theories and expectations. In: Beets, G. (ed.). Population and family in the Low Countries 1993: Late fertility and other current issues. NIDI/CBGS Publication: 81-126.

Zakharov, S. (2008). Russian Federation: From the first to second demographic transition. Demographic Research 19(24): 907-972. doi:10.4054/DemRes. 2008.19.24.

Zembrzuska, A. (2000). The Socialist Model of Woman in Poland and its Soviet Prototype. In: Rogers, D., Wheeler, J., Zavacká, M., and Casebier, S. (eds.). Topics in Feminism, History and Philosophy. Vienna: IWM Junior Visiting Fellows Conferences. 


\section{Appendix}

Table A1: The selected cohorts by education, unweighted sample

\begin{tabular}{|c|c|c|c|c|c|c|c|}
\hline cohort & $\begin{array}{l}\text { primary and } \\
\text { lower }\end{array}$ & $\begin{array}{c}\text { lower } \\
\text { secondary }\end{array}$ & $\begin{array}{c}\text { upper } \\
\text { secondary }\end{array}$ & tertiary & $\begin{array}{c}\text { education not } \\
\text { known }\end{array}$ & $\begin{array}{c}\text { unknown number of } \\
\text { children }\end{array}$ & all \\
\hline 1930 & 2116 & 131 & 380 & 79 & 7 & 18 & 2731 \\
\hline 1931 & 1969 & 141 & 436 & 92 & 5 & 25 & 2668 \\
\hline 1932 & 1968 & 194 & 500 & 96 & 7 & 27 & 2792 \\
\hline 1933 & 1824 & 169 & 559 & 119 & 3 & 29 & 2703 \\
\hline 1934 & 1860 & 191 & 579 & 144 & 2 & 20 & 2796 \\
\hline 1935 & 1837 & 200 & 665 & 157 & 1 & 28 & 2888 \\
\hline 1936 & 1801 & 241 & 714 & 191 & 2 & 31 & 2980 \\
\hline 1937 & 1719 & 254 & 717 & 190 & 6 & 27 & 2913 \\
\hline 1938 & 1751 & 245 & 703 & 191 & 3 & 24 & 2917 \\
\hline 1939 & 1769 & 250 & 678 & 194 & 4 & 29 & 2924 \\
\hline 1940 & 1700 & 225 & 717 & 223 & 2 & 14 & 2881 \\
\hline 1941 & 1519 & 236 & 667 & 238 & 2 & 20 & 2682 \\
\hline 1942 & 1557 & 275 & 635 & 222 & 1 & 15 & 2705 \\
\hline 1943 & 1386 & 351 & 606 & 220 & 4 & 22 & 2589 \\
\hline 1944 & 1347 & 349 & 784 & 218 & 2 & 23 & 2723 \\
\hline 1945 & 1255 & 392 & 836 & 215 & 2 & 17 & 2717 \\
\hline 1946 & 1517 & 709 & 1219 & 333 & 5 & 24 & 3807 \\
\hline 1947 & 1557 & 791 & 1405 & 361 & 7 & 29 & 4150 \\
\hline 1948 & 1589 & 953 & 1614 & 414 & 3 & 30 & 4603 \\
\hline 1949 & 1517 & 990 & 1687 & 403 & 2 & 34 & 4633 \\
\hline 1950 & 1438 & 1095 & 1851 & 474 & 4 & 25 & 4887 \\
\hline 1951 & 1427 & 1202 & 2008 & 483 & 6 & 27 & 5153 \\
\hline 1952 & 1416 & 1247 & 2088 & 466 & 4 & 32 & 5253 \\
\hline 1953 & 1341 & 1354 & 2197 & 552 & 5 & 17 & 5466 \\
\hline 1954 & 1340 & 1460 & 2219 & 586 & 7 & 38 & 5650 \\
\hline 1955 & 1350 & 1382 & 2345 & 589 & 5 & 23 & 5694 \\
\hline 1956 & 1220 & 1539 & 2519 & 599 & 6 & 22 & 5905 \\
\hline 1957 & 1021 & 1640 & 2601 & 628 & 6 & 19 & 5915 \\
\hline 1958 & 899 & 1583 & 2588 & 608 & 2 & 23 & 5703 \\
\hline 1959 & 822 & 1621 & 2449 & 623 & 5 & 21 & 5541 \\
\hline
\end{tabular}


Brzozowska: Fertility and education in Poland during state socialism

Figure A1: Cumulative distribution by cohort and education at the time of the interview (in per cent)

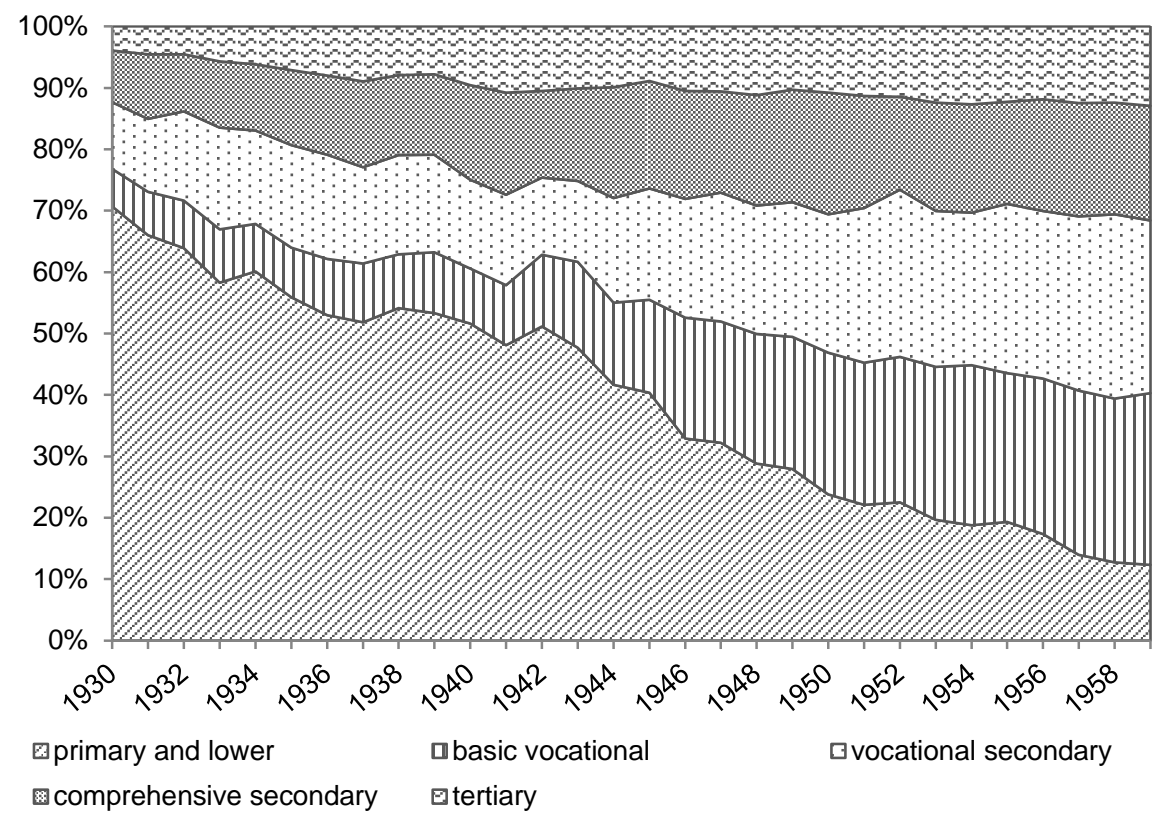


Table A2: Completed fertility calculated from (1) the Fertility Survey 2002 (1a) measured at age 43, (1b) with no age limits, and given by the (2) Council of Europe

\begin{tabular}{|c|c|c|c|}
\hline cohort & (1a) CFR at 43 & $\begin{array}{l}\text { (1b) CFR completed } \\
\text { (no age restrictions) }\end{array}$ & (2) CFR Council of Europe \\
\hline 1930 & 2.55 & 2.56 & 2.78 \\
\hline 1931 & 2.52 & 2.53 & \\
\hline 1932 & 2.55 & 2.56 & \\
\hline 1933 & 2.41 & 2.42 & \\
\hline 1934 & 2.53 & 2.55 & \\
\hline 1935 & 2.48 & 2.49 & 2.60 \\
\hline 1936 & 2.44 & 2.45 & \\
\hline 1937 & 2.33 & 2.34 & \\
\hline 1938 & 2.34 & 2.35 & \\
\hline 1939 & 2.29 & 2.30 & \\
\hline 1940 & 2.28 & 2.29 & 2.41 \\
\hline 1941 & 2.21 & 2.21 & \\
\hline 1942 & 2.23 & 2.24 & \\
\hline 1943 & 2.26 & 2.26 & \\
\hline 1944 & 2.14 & 2.15 & \\
\hline 1945 & 2.26 & 2.26 & 2.27 \\
\hline 1946 & 2.14 & 2.15 & \\
\hline 1947 & 2.16 & 2.17 & \\
\hline 1948 & 2.19 & 2.19 & \\
\hline 1949 & 2.17 & 2.17 & \\
\hline 1950 & 2.14 & 2.15 & 2.19 \\
\hline 1951 & 2.17 & 2.17 & \\
\hline 1952 & 2.15 & 2.16 & \\
\hline 1953 & 2.19 & 2.20 & \\
\hline 1954 & 2.19 & 2.20 & \\
\hline 1955 & 2.23 & 2.23 & 2.17 \\
\hline 1956 & 2.23 & 2.23 & \\
\hline 1957 & 2.18 & 2.19 & \\
\hline 1958 & 2.21 & 2.21 & 2.21 \\
\hline 1959 & 2.25 & 2.25 & 2.20 \\
\hline
\end{tabular}

Note: 1ab were calculated using the whole sample (including cases with missing education).

The Council of Europe estimated CFR at age 49. For cohorts younger than 49 at the time of measurement they imputed the fertility at the missing reproductive ages, using the fertility rates of the most recently observed cohorts (Council of Europe, 2005). 
Brzozowska: Fertility and education in Poland during state socialism

Table A3: The decomposed change in the standardised CFR into changes in the standardised ASFRs, over consecutive five-year cohorts

\begin{tabular}{lcccccc}
\hline agelcohort & $1935-39$ & $1940-44$ & $1945-49$ & $1950-54$ & $1955-59$ & 1955-59 compared to 1930-34 \\
\hline $15-19$ & 0.02 & 0.02 & -0.01 & -0.01 & 0.02 & 0.05 \\
$20-24$ & 0.05 & -0.03 & -0.01 & 0.02 & 0.07 & 0.09 \\
$25-29$ & -0.08 & -0.06 & 0.05 & 0.05 & 0.04 & -0.02 \\
$30-34$ & -0.03 & -0.02 & 0.03 & 0.02 & -0.04 & -0.02 \\
$35-43$ & 0.00 & -0.03 & 0.02 & -0.01 & -0.01 & -0.02 \\
\hline
\end{tabular}

